DOI: 10.32844/2222-5374-2020-104-2.62

УДК: 349.2

Таможанський О. В., здобувач кафедри правознавства Східноукраїнського національного університету імені Володимира Даля

\title{
ЗАРУБІЖНИЙ ДОСВІД ПРАВОВОГО РЕГУЛЮВАННЯ ЗАПРОВАДЖЕННЯ ГНУЧКИХ ФОРМ ПРАЦІ
}

Актуальність статті полягає в тому, що під впливом посилення гнучкості у правовому регулюванні трудових правовідносин, роботодавець зацікавлений у встановленні атипових трудових правовідносин; в результаті чого працівники знаходяться у менш вигідному становищі, ніж працівники, які здійснюють свою трудову функцію за безстроковими договорами. Метою статті є аналіз правового регулювання запровадження гнучких форм організації праці у таких зарубіжних країнах, як Бельгія, Франція, Великобританія. Стаття присвячена аналізу зарубіжного досвіду запровадження новітніх форм організації праці. Зазначається, що для вдосконалення вітчизняного правового регулювання з цих питань видається цікавим досвід економічно розвинених країн із правового регулювання запровадження гнучких форм організації праці Зокрема, автором досліджено першоджерела з цих питань таких країн як Бельгія, Франція, Великобританія. Зроблено висновок, що дистанційна робота в Бельгї - це специфічна умова, яка стосується лише працівників, які перебувають у трудових відносинах з роботодавцем, та яка $\epsilon$ скоріш винятком, аніж загальним правилом. Дистанційна робота визначається як форма організації та виконання роботи з використанням інформаційних технологій на підставі трудового договору, внаслідок чого діяльність, яка може виконуватися в місцезнаходженні роботодавців, виконується за межами місцезнаходження регулярно або періодично. Для дистанційних працівників роботодавець повинен надати належні інструменти для виконання своєї роботи та вберегти працівника від соціальної ізоляції, дозволивши йомузустрічатися з колегами, отримувати такуж інформацію, що і працівники на місці роботи. Починаючи з 2000-х років у французькій системі трудового права дедалі частіше починає обговорюватися гнучкість організації праці. Це свідчило про те, що Франція, яку часто розглядають як країну з жорстким 35-годинним робочим тижнем, зазнала значних змін у регулюванні робочого часу в останні десятиліття, включаючи поступове скасування 35-годинних законів про робочий тиждень. У Великобританії не передбачено право працівника в односторонньому порядку змінити або скоротити свій робочий час через причини балансу між роботою та сімуєю; однак є право вимагати внесення змін до графіку роботи за умови отримання певної кваліфікації. 
Ключові слова: трудові правовідносини, працівник, роботодавець, гнучкість, атипова зайнятість, дистанційна робота, надомна робота.

Актуальність теми. Під впливом посилення гнучкості у правовому регулюванні трудових правовідносин, роботодавець зацікавлений у встановленні атипових трудових правовідносин; в результаті чого працівники знаходяться у менш вигідному становищі, ніж працівники, які здійснюють свою трудову функцію за безстроковими договорами. Гнучкість правового регулювання трудових відносин означаєукладення трудових договорів на умовах неповного робочого часу, з гнучким режимом роботи, з надомними та дистанційними працівниками та ін. Відтак, для удосконалення вітчизняного правового регулювання з цих питань, видається цікавим досвід економічно розвинених країн із правового регулювання запровадження гнучких форм організації праці.

Аналіз останніх досліджень і публікацій з теми. Питання впливу гнучкості на зміну уявлень про організацію процесу праці цікавили деяких зарубіжних науковців, як-от: Е.М. Бородіну [1], Н.Р. Нікітіну [2], К.Л. Томашевського [3], О.Є. Коркіна [4], О.С. Чанишева [5] та ін.

Метою статті $€$ аналіз правового регулювання запровадження гнучких форм організації праці у таких зарубіжних країнах, як Бельгія, Франція, Великобританія.

Виклад основного матеріалу. У бельгійській правовій системі встановлено денний та тижневий ліміт робочого часу. Стаття 19 Закону про зайнятість (далі - Arbeidswet - EA) передбачає тижневий ліміт робочого часу 38 годин на тиждень і 8 годин на день. Але цей денний ліміт збільшується до 9 годин, якщо працівник користується більше ніж одним вихідним днем на тиждень.

За результатами соціального діалогу сторони можуть за допомогою колективних договорів знизити тижневий ліміт, у результаті чого передбачається компенсаційний відпочинок або оплата понаднормової роботи. Максимальний робочий час також може бути зменшений у ПВТР або за індивідуальною трудовою угодою, але в такому випадку межі компенсаційного відпочинку та надурочних робіт не знижуються. Разом 3 цим, тижневий ліміт робочого часу також може бути і вищим. Якщо колективний договір передбачає, то максимальний тижневий робочий час може сягати 40 годин на тиждень та, надаючи при цьому 12 додаткових компенсаційних днів відпочинку.

Гнучка форма організації праці дозволяє компанії встановлювати змінні графіки робочого часу, які можуть змінюватися щонайбільше на 2 години більше або менше на день, ніж звичайний денний ліміт робочого часу, і максимум на 5 годин більше або менше на день, ніж звичайний тижневий робочий час та максимум 45 годин на тиждень (article 20bis $E A)$.

Також гнучкість дозволяє компанії встановлювати змінні графіки робочого часуз максимум 12 годин на день. Вони можуть бути запроваджені шляхом адаптації трудового розпорядку або укладення колективних договорів. Більше того, хоча соціальна інспекція не регулюється 
законодавством, соціальні інспекції приймають змінні графіки робочого часу для всіх працівників, які працюють повний робочий день (для працівників, які працюють на умовах неповного робочого часу, це регулює закон). Працівник заздалегідь знає свій графік за 5 днів і робочий час стабільний в середньому протягом 3 місяців (який може бути продовжений максимум на 1 рік), але роботодавець може в односторонньому порядку вирішити, коли працівник повинен працювати [6].

Дистанційна робота в Бельгії - це специфічна умова, яка стосується лише працівників, що перебувають у трудових відносинах з роботодавцем, та яка $\epsilon$ скоріш винятком, аніж загальним правилом. Правовою базою $\epsilon$ Collective Agreement Nr 85 and 85bis між соціальними партнерами. Про це було погоджено у 2005 та 2008 роках для того, щоб відповідати Європейській рамковій угоді 2002 року.

Надомна робота у Бельгії також існує як форма трудових відносин, яка застосовується до робіт, які завжди виконуються на дому чи з іншого місця, за певним типом договору, без нагляду роботодавця. Хоча спочатку це стосувалося ручної роботи, наразі надомною може бути й інтелектуальна праця. Але, зазвичай, працівники в Бельгії на такій роботі є самозайнятими.

y Collective Agreement Nr 85 дистанційна робота визначається як форма організації та виконання роботи з використанням інформаційних технологій на підставі трудового договору, внаслідок чого діяльність, яка може виконуються в місцезнаходженні роботодавців, виконується за межами місцезнаходження регулярно або періодично.

Це визначення означає, що необхідно використовувати IКТ та, що діяльність здійснюється в іншому місці (не обмежуючись будинком працівників), яке не належить роботодавцю. Тому ця угода не поширюється на працівників, які працюють в іншому місці, але наданому роботодавцем, наприклад, в децентралізованому місці або в тому, що часто називають супутниковим розташуванням. Окрім цього, наведене визначення акцентує увагу на регулярні та періодичні дії, і не випадково, адже приписи щодо такого видку роботи не застосовується до так званих «випадкових дистанційних робіт». Як наслідок, деякі роботодавці зацікавлені у тому, щоб їх домовленості про дистанційну роботу вважалася «випадковою», щоб уникнути витрат, що виникають у зв'язку із оплатою регулярної чи періодичної роботи.

Проте вже у 2017 р. було затверджено закон, який забезпечує правову основу для «випадкових дистанційних робіт» у випадках «форс-мажорних обставин» працівника, таких як зупинка громадського транспорту або особисті причини, що унеможливлюють роботу працівника в приміщенні роботодавців. Згідно з цим новим законом права та режим робочого часу для таких «випадкових» працівників, які працюють в дистанційному режимі, однакові, як і для звичайних працівників. Це гарантує, що на всіх працівників, які працюють у дистанційному режимі поширюється загальний правовий статус.

Дистанційна робота вимагає включення окремих приписів в колективні угоди компанії та укладення додатку до окремих контрактів. Умови праці, включаючи норми робочого часу, повинні бути однаковими для роботи на дистанції, як і для роботи на місці роботи [7]. 
У Бельгії для дистанційних працівників роботодавець повинен надати працівникові належні інструменти для виконання своєї роботи та вберегти працівника від соціальної ізоляції, дозволивши йому зустрічатися з колегами, отримувати такуж інформацію, що і працівники на місці роботи. Робочий час може бути організований працівником на свій розсуд, але відповідно до регламенту робочого часу компанії. На практиці це означає, що дистанційний працівник повинен виконувати такий же обсяг роботи, як і офісний працівник, але він може вибирати свій робочий час. Показники робочого навантаження та ефективності повинні бути такими ж, як для працівників офісу. Роботодавець повинен повідомити дистанційного працівника про політику охорони праці компанії, а працівник повинен дозволити службам профілактики на роботі отримати доступ до свого робочого місця, щоб оцінити, чи виконуються норми з охорони праці. Важливо, що дистанційний працівник може вимагати проведення такої перевірки [8, с. 3-10].

У правовій системі Франції встановлено щоденний, щотижневий та щорічний максимальний робочий час. Відповідно до ст. L. 3121-10 французького Трудового кодексу, робочий час для більшості працівників становить 35 годин на тиждень. Він не може перевищувати 1607 годин на рік. Кожна година, відпрацьована понад цей поріг, вважається понаднормовою і дає право працівникові на надбавку за понаднормовий час за спеціальною ставкою та / або дні відпочинку [9, с. 55-60].

Французьке законодавство передбачає, що працівники, які працюють понад 220 надурочних годин на рік, мають право - крім оплати цих надурочних годин - на додатковий оплачуваний відпочинок. Цей ліміт також може бути визначений за допомогою колективного договору, який встановлює практичні умови понаднормової роботи на підприємстві. За умови, що роботодавець не вимагає від працівника працювати понад законодавчі межі, працівник не має права відмовитись працювати понаднормово. Роботодавець може вимагати від працівника роботи, що перевищує законодавчо визнаний рівень понаднормової роботи, лише якщо він проконсультувався 3 робочою радою або з представниками персоналу.

Починаючи з 2000-х років у французькій системі трудового права дедалі частіше починає обговорюватися гнучкість організації праці. У 2003 році кількість понаднормових годин збільшено до 220, у 2007 році це звільнення від податку на прибуток та соціальних внесків робітників на оплатупонаднормовихробіттаскороченнясоціальнихвнесківроботодавця; у 2008 році філіальні чи фірмові угоди фіксують максимальну кількість надурочних робіт. Це свідчило про те, що Франція, яку часто розглядають як країну з жорстким 35-годинним робочим тижнем, зазнала значних змін у регулюванні робочого часу в останні десятиліття, включаючи поступове скасування 35-годинних законів про робочий тиждень.

Як приклад, відповідно до Law n 2013-504 of June 2013 про безпеку робочих місць, article L. 5125-1 to L. 5125-7 of the Labor Code вводить нову категорію колективних договорів: угоду «про збереження зайнятості». У компаніях, які стикаються з серйозними циклічними економічними труднощами, ці угоди повинні допомогти тимчасово відрегулювати 
організацію робочого часу та оплату праці, уникаючи звільнень. Ці угоди укладаються між роботодавцем та представниками працівників. Щоб бути дійсними, вони повинні бути підписані однією або кількома профспілками, що представляють принаймні 50\% голосів, поданих на останніх професійних виборах. Спеціальні положення застосовуються до компаній, які не мають профспілок. Угода про підтримку зайнятості спрямована на коригування організації робочого часу та оплати праці. Натомість роботодавець зобов'язується підтримувати роботу протягом усього періоду дії угоди. Це може включати, наприклад, зменшення винагороди та робочого часу або збільшення робочого часу без збільшення винагороди. Угода може застосовуватися до всіх співробітників або лише до певної частини робочої сили.

УВеликобританіїнепередбаченоправопрацівникаводносторонньому порядку змінити або скоротити свій робочий час через причини балансу між роботою та сім>єю; однак є право вимагати внесення змін до графіку роботи за умови отримання певної кваліфікації.

Право вимагати гнучких режимів роботи було запроваджено Законом про зайнятість 2002 р., який включив ss.80F-80I до Закон про право на зайнятість 1996 року. Коли він був запроваджений спочатку, він обмежувався проханнями про догляд за маленькою дитиною або дитиноюінвалідом; однак згодом це право було доповнено, і після внесення змін, остання з яких передбачена Законом про дітей та сім>ї 2014 року, це право тепер доступне всім працівникам, які відповідають певній кваліфікації.

Працівники, які постійно працювали у свого роботодавця протягом принаймні 26 тижнів на дату запиту, і які не подавали запит протягом попередніх 12 місяців, можуть подати запит про встановлення гнучкого робочого часу. Під час подання запиту працівник, як зазначено в с. 80F (1) (a) Закону про права на зайнятість, має три варіанти: (1) зміна робочого часу, (2) запровадження роботи вдома (надомної) або (3) їх поєднання. Отже, обсяг запиту досить широкий і може призвести до широкого кола різних типів запитів, які $є$ унікальними для потреб працівника. Запит повинен бути оформлений у письмовій формі, у ньому повинна бути вказана дата, з якої вимагається внесення змін, а також пояснення наслідків (якщо такі існують), які можуть виникнути для роботодавця, а також думки щодо того, як їх можна уникнути.

Слід зазначити, що це право $є$ лише правом на запит, і роботодавець може відмовити узадоволенні клопотання, якщо воно грунтується на одній або декількох статутних причинах, що містяться в п. 80G Закону про права на зайнятість 1996 року: тягар додаткових витрат; шкідливий вплив на здатність задовольнити попит споживачів; неможливість реорганізувати роботу серед існуючого персоналу; неможливість набору додаткового персоналу; шкідливий вплив на якість продукції чи послуг; шкідливий вплив на ефективність роботи; недостатній обсяг роботи в періоди, коли працівник пропонує працювати.

Існує два аспекти зміни робочого часу з метою досягнення гнучкості: один спрямований на молодих працівників, а інший - на всіх інших. Усі молоді працівники віком від 16 до 17 років у Шотландії та Уельсі, які не мають денної середньої або подальшої освіти і які ще не досягли 
необхідного рівня кваліфікації, мають право на гнучкий час роботи з метою навчання. Це право мають і молоді працівники у віці 18 років, які мали б це право, якщо їм було 16 чи 17 років, якщо вони вже розпочали навчання, що призведе до отримання відповідної кваліфікації.

Кількість перерв у роботі становить, як зазначається у законодавстві Великобританії, - «в розумних межах за конкретних обставин». Це означатиме, що певний час можуть враховуватися не лише вимоги відповідного курсу навчання, але й потреби роботодавця. Право на перерву підкріплюється забезпеченням оплати праці, яка повинна виплачуватися за тією ж ставкою, яку зазвичай отримував би працівник, якщо працював.

Разом з цим, існує обмежене право вимагати відпустки для навчання тим, хто $\epsilon$ молодшими працівниками, адже тільки «кваліфіковані працівники» мають право подати заяву, а роботодавець зобов>язаний розглянути іiі. Кваліфікованим працівником $\epsilon$ працівник старшого шкільного віку, який має 26 тижнів безперервної служби та не подавав заявку протягом попередніх 12 місяців щодо надання йому відпустки. Важливо, що право застосовується лише на робочих місцях, деу роботодавця працює щонайменше 250 працівників. Важливою частиною заявки $\epsilon$ вимога надати інформацію про те, як майбутнє навчання або тренінг може підвищити ефективність роботи працівників у бізнесі роботодавця та результати його діяльності [10].

Останнім часом регулювання робочого часу у Великобританії певною мірою збільшило гнучкість в управлінні робочим часом. Однак підхід законодавства Великобританії, який з одного боку надає право на запит щодо встановлення гнучкого робочого часу лише кваліфікованим працівникам, втім, з іншого боку - передбачає досить широкий перелік законодавчо обумовлених причин відмови задоволення роботодавцем такого запиту працівника [11, с. 66-74].

Висновки. Дистанційна робота в Бельгії - це специфічна умова, яка стосується лише працівників, що перебувають у трудових відносинах з роботодавцем, та яка є скоріш винятком, аніж загальним правилом. Дистанційна робота визначається як форма організації та виконання роботи 3 використанням інформаційних технологій на підставі трудового договору, внаслідок чого діяльність, яка може виконуються в місцезнаходженні роботодавців, виконується за межами місцезнаходження регулярно або періодично. Надомна робота у Бельгії також існує як форма трудових відносин, яка застосовується до робіт, які завжди виконуються на дому чи з іншого місця, за певним типом договору, без нагляду роботодавця. Хоча спочатку це стосувалося ручної роботи, наразі надомною може бути й інтелектуальна праця. Але, зазвичай, працівники в Бельгії на такій роботі $є$ самозайнятими.

У Бельгії для дистанційних працівників роботодавець повинен надати працівникові належні інструменти для виконання своєї роботи та вберегти працівника від соціальної ізоляції, дозволивши йому зустрічатися 3 колегами, отримувати таку ж інформацію, що і працівники на місці роботи. Робочий час може бути організований працівником на свій розсуд, але відповідно до регламенту робочого часу компанії. На практиці це означає, що дистанційний працівник повинен виконувати такий же обсяг роботи, як 
і офісний працівник, але він може вибирати свій робочий час. Показники робочого навантаження та ефективності повинні бути такими ж, як для працівників офісу. Роботодавець повинен повідомити дистанційного працівника про політику охорони праці компанії, а працівник повинен дозволити службам профілактики на роботі отримати доступ до свого робочого місця, щоб оцінити, чи виконуються норми з охорони праці. Важливо, що дистанційний працівник може вимагати проведення такої перевірки

Починаючи 3 2000-х років у французькій системі трудового права дедалі частіше починає обговорюватися гнучкість організації праці. У 2003 році кількість понаднормових годин збільшено до 220, у 2007 році це звільнення від податку на прибуток та соціальних внесків робітників на оплату понаднормових робіт та скорочення соціальних внесків роботодавця; у 2008 році філіальні чи фірмові угоди фіксують максимальну кількість надурочних робіт. Це свідчило про те, що Франція, яку часто розглядають як країну з жорстким 35-годинним робочим тижнем, зазнала значних змін у регулюванні робочого часу в останні десятиліття, включаючи поступове скасування 35-годинних законів про робочий тиждень.

УВеликобританіїнепередбаченоправопрацівникаводносторонньому порядку змінити або скоротити свій робочий час через причини балансу між роботою та сім>єю; однак є право вимагати внесення змін до графіку роботи за умови отримання певної кваліфікації.

\section{СПИСОК ВИКОРИСТАНИХ ДЖЕРЕЛ}

1. Бородина Е. Н. Особенности правового регулирования труда лиц, работающих вне места нахождения работодателя: дис. ... канд. юрид. наук: 12.00.05. Москва, 2019. 212 с.

2. Никитина Н. Р. Режим рабочего времени и его виды: дис. ... канд. юрид. наук: 12.00.05. Москва, 2011. 170 с.

3. Томашевский К. Л. Компьютерное надомничество (телеработа) как одна из гибких форм занятости в XXI в. Трудовое право в России и за рубежом. 2011. № 3. С. 32-35.

4. Коркин А. Е. Нетипичные трудовые отношения: заемный труд, телеработа и работа по вызову: моногр. Москва: Инфотропик Медиа, 2013. $208 \mathrm{c}$.

5. Чанышев А. С. Правовое регулирование рабочего времени и времени отдыха в странах Скандинавии: моногр. Москва: Проспект, 2016. 128 с.

6. Le temps de travail: transformations du droit et des relations collectives du travail / Jamoulle M. et al. Brussel CRISP, 1997, 519 p.

7. Delagrange H. Teleworking and Labor Conditions in Belgium. IUS Labor.2017. № 2. P. 3-7.

8. Sarah De Groof Working time and flexibility in Belgium. IUS Labor. № 1. 2016. 167 p.

9. Delsen L., Bauer F., Cette G., Smith M. Comparative Analyses in the European Union and Working Times of Operating Hours. Springer Dordrecht Heidelberg. London-New York, 2009. 218 p.

10. Section 63E(4)(b) of the Employment Rights Act 1996.

11. Butler M. Working time and flexibility in the United Kingdom. IUS Labor. № 1. 2016. P. 66-74. 


\section{O. Tamozhanskyi}

\section{FOREIGN EXPERIENCE OF LEGAL REGULATION OF INTRODUCTION OF FLEXIBLE FORMS OF LABOR}

The relevance of the article is that under the influence of increasing flexibility in the legal regulation of labor relations, the employer is interested in establishing atypical labor relations; as a result, employees are in a less favorable position than employees who perform their employment function under permanent contracts. The aim of the article is to analyze the legal regulation of the introduction offlexible forms of labor organization in such foreign countries as Belgium, France, Great Britain. The article is devoted to the analysis of foreign experience of introduction of the newest forms of the organization of work. It is noted that in order to improve the domestic legal regulation on these issues, the experience of economically developed countries in the legal regulation of the introduction of flexible forms of labor organization seems interesting. It has been concluded that teleworking in Belgium is a specific condition which applies only to employees who are in an employment relationship with an employer and which is the exception rather than the general rule. Remote work is defined as a form of organization and performance of work using information technology on the basis of an employment contract, as a result of which activities that can be performed at the location of employers are performed outside the location regularly or periodically. For teleworkers, the employer must provide the appropriate tools to carry out their work and protect the worker from social exclusion by allowing him to meet with colleagues and receive the same information as workers at work. Since the 2000s, the French labor law system has increasingly begun to discuss the flexibility of labor organization. This indicated that France, often seen as a country with a strict 35-hour working week, has undergone significant changes in working time regulation in recent decades, including the phasing out of 35-hour working week laws. The United Kingdom does not provide for the right of a worker to unilaterally change or reduce his working hours for reasons of work-life balance; however, there is a right to require changes to the work schedule subject to obtaining a certain qualification.

Keywords: labor relations, employee, employer, flexibility, atypical employment, remote work, home work. 